\title{
Peningkatan Kualitas Kecap Nira Lontar dengan Penambahan Tepung Tempe
}

\author{
Enhancement of Lontar Palm Sauce Quality by Tempeh Flour Addition \\ Linda N. Suenan ${ }^{1}$, Melissa E.S. Ledo ${ }^{1 *}$, dan James Ngginak ${ }^{1}$ \\ ${ }^{1}$ Jurusan Pendidikan Biologi, Fakultas Keguruan dan Ilmu Pendidikan, \\ Universitas Artha Wacana, Kupang, Indonesia
}

\begin{abstract}
Abstrak
Kecap nira lontar adalah jenis kecap tradisional yang umum dibuat oleh masyarakat suku Rote, Nusa Tenggara Timur melalui proses karamelisasi nira dari tanaman lontar dengan metode pemanasan. Penambahan tepung tempe sebagai sumber protein nabati berpotensi meningkatkan kandungan gizi kecap nira lontar. Penelitian ini bertujuan untuk mempelajari pengaruh penambahan tepung tempe pada peningkatan nilai protein dan citarasa kecap nira lontar. Metode yang digunakan adalah metode eksperimen dengan penambahan variasi konsentrasi tepung tempe yaitu yaitu $0 \%, 3 \%, 5 \%, 7 \%$, dan $10 \%$ pada kecap nira lontar. Tahapan penelitian meliputi proses pembuatan kecap nira lontar, uji protein kecap nira lontar dan uji organoleptik. Kandungan protein pada kecap nira lontar meningkat sebanding dengan konsentrasi tepung tempe yang ditambahkan. Uji organoleptik terhadap kecap nira lontar yang diperkaya tepung tempe menunjukkan perbedaan antar perlakuan. Penambahan tepung tempe pada kecap nira lontar meningkatkan kandungan protein dan citarasanya.
\end{abstract}

Kata Kunci: Kecap nira lontar, tepung tempe, protein

\begin{abstract}
Lontar palm sauce is a traditional sauce made by Rotenese of East Nusa Tenggara, which applied caramelization process of lontar palm sap. Tempeh flour could be used as a potential ingredient to increase the protein content of lontar palm sauce. The aim of this research was to study the effect of tempeh flour addition on the increase of protein value and savour of lontar palm sauce. This research employed five concentration of tempeh flour which are $0 \%, 3 \%, 5 \%, 7 \%$, and $10 \%$. Three steps of experiment consist of lontar palm sauce production, protein assay and organoleptic test. The increased of tempeh flour concentration that was used in enrichment led to the increase of protein content of lontar palm sauce. Organoleptic test of tempeh flourenriched lontar palm sauces showed diferrence between each treatment. The addition of tempeh flour increased protein content and savour of lontar palm sauce.
\end{abstract}

Keyword : Lontar palm sauce, tempeh flour, protein

\footnotetext{
*Corresponding author:

Melissa E.S. Ledo

Jurusan Pendidikan Biologi, Fakultas Pendidikan dan Ilmu Pendidikan, Universitas Artha Wacana Jl. Adi Scucipto No.147, Oesapa, Kupang, Indonesia, 85361

E-mail : mellissaerlynsledo@gmail.com
} 


\section{Pendahuluan}

Nusa Tenggara Timur dikenal sebagai daerah memiliki sebaran tumbuhan lontar yang luas. Dalam sejarah kehidupan masyarakat Nusa Tenggara Timur, terlebih masyarakat suku Rote dan Sabu, pohon lontar adalah salah satu tumbuhan penopang kehidupan. Pohon lontar dikenal juga oleh masyarakat setempat dengan nama lokal pohon tuak. Kehadiran lontar sebagai sumber penopang kehidupan tidak terlepas dari berbagai pemanfaatannya, seperti batang untuk bahan bangunan, daun untuk perabot rumah tangga, air sadapan sebagai bahan baku pembuatan aneka bahan pangan seperti kecap, gula air dan kue (Sasangko, 2008). Kecap nira lontar sebagai salah satu bentuk pemanfaatan lontar sebagai bahan pangan oleh masyarakat setempat membutuhkan bahan dasar berupa nira yang disadap dari mayang lontar.

Kecap merupakan produk pangan cair berwarna gelap yang mempunyai rasa asin atau manis. Pada umumnya, kecap dibuat dari bahan dasar berupa kacang kedelai. Kecap banyak digunakan sebagai penyedap masakan oleh masyarakat Indonesia karena memiliki zat gizi berupa karbohidrat, vitamin, mineral dan protein (Astawan, 2004). Menurut Snyder dan Kwon (1987) kedelai mengandung 40,5\% protein, 20,5\% lemak, karbohidrat 22,2\%, serat kasar 4,3\%, abu $4,5 \%$, dan air $6,6 \%$ tiap satuan berat $100 \mathrm{~g}$.

Nira yang disadap dari pohon lontar biasanya mempunyai komposisi $75-90 \%$ sukrosa, 0,50-1,00\% gula reduksi, 0,02\%, lemak, $0,03 \%$ abu dan $0,35 \%$ protein (Naiola, 2008). Rendahnya nilai protein dalam nira lontar ini menyebabkan rendahnya kadar protein dalam produk kecap nira lontar yang dihasilkan. Salah satu cara dalam meningkatkan kandungan protein kecap nira lontar adalah dengan penambahan tepung tempe. Tempe adalah salah satu makanan tradisional yang terbuat dari kedelai. Menurut Mardiah (1994), hasil analisis proksimat tepung tempe mempunyai kandungan protein $48 \%$, lemak $24,7 \%$, karbohidrat $13,5 \%$, serat $2,5 \%$ dan abu 2,3\% .

Pembuatan kecap merupakan peluang terciptanya industri pangan yang menjanjikan. Potensi pembuatan kecap berbahan dasar nira lontar sangat menjanjikan untuk dikembangkan di daerah Nusa Tenggara Timur karena melimpahnya ketersediaan bahan dasar dari pohon lontar. Penambahan tepung tempe pada kecap nira lontar bisa meningkatkan kandungan gizi khususnya pada nilai protein pada produk kecap nira

Tabel 1. Kandungan protein kecap nira lontar

\begin{tabular}{clc}
\hline No & \multicolumn{1}{c}{$\begin{array}{c}\text { Perlakuan Nira Lontar dan } \\
\text { Tepung Tempe (\%) }\end{array}$} & $\begin{array}{c}\text { Kandungan } \\
\text { Protein (\%) }\end{array}$ \\
\hline 1 & $\begin{array}{l}\text { Kecap Nira Lontar Dengan } \\
\text { Penambahan 0\% Tepung } \\
\text { Tempe (A1) (kontrol) }\end{array}$ & 2,58 \\
2 & $\begin{array}{l}\text { Kecap Nira Lontar Dengan } \\
\text { Penambahan 3\% Tepung } \\
\text { Tempe (A2) }\end{array}$ \\
3 & $\begin{array}{l}\text { Kecap Nira Lontar Dengan } \\
\text { Penambahan 5\% Tepung } \\
\text { Tempe (A3) }\end{array}$ \\
4 & $\begin{array}{l}\text { Kecap Nira Lontar Dengan } \\
\text { Penambahan 7\% Tepung } \\
\text { Tempe (A4) }\end{array}$ \\
Kecap Nira Lontar dengan \\
penambahan tepung tempe \\
10\% (A5)
\end{tabular}
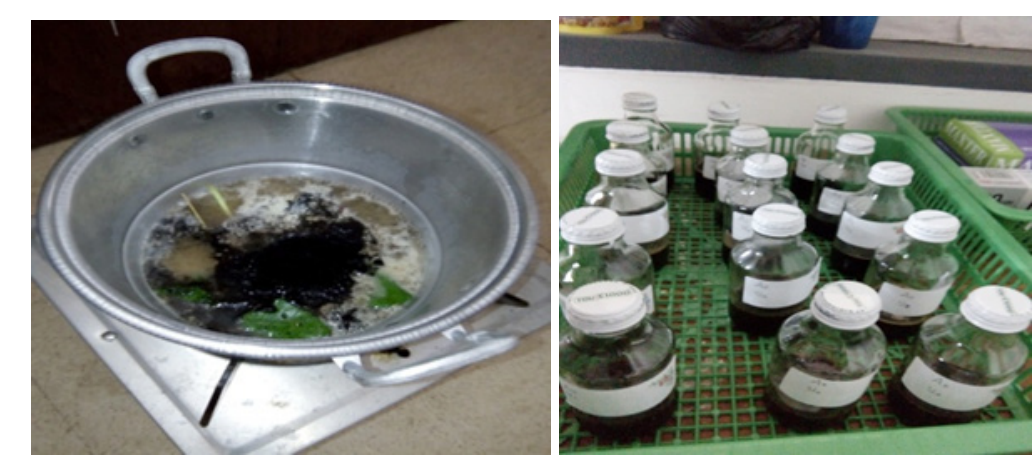

Gambar 1. Pembuatan kecap nira lontar dengan variasi tepung tempe 
Tabel 2. Hasil Uji BNT kesukaan panelis terhadap warna, kekentalan, aroma dan rasa kecap nira lontar

\begin{tabular}{clcccc}
\hline No & $\begin{array}{c}\text { Penambahan } \\
\text { Tepung Tempe }\end{array}$ & $\begin{array}{c}\text { Rerata } \\
\text { (Warna) }\end{array}$ & $\begin{array}{c}\text { Rerata } \\
\text { (Kekentalan) }\end{array}$ & $\begin{array}{c}\text { Rerata } \\
\text { (Aroma) }\end{array}$ & $\begin{array}{c}\text { Rerata } \\
\text { (Rasa) }\end{array}$ \\
\hline 1 & $0 \%(\mathrm{~A} 1)$ & 4,00 & 3,73 & 3,47 & 3,57 \\
2 & $3 \%(\mathrm{~A} 2)$ & 4,37 & 3,90 & 3,77 & 3,93 \\
3 & $5 \%(\mathrm{~A} 3)$ & 4,20 & 4,33 & 3,87 & 4,23 \\
4 & $7 \%(\mathrm{~A} 4)$ & 4,40 & 3,80 & 3,67 & 4,37 \\
5 & $10 \%(\mathrm{~A} 5)$ & 5,27 & 5,40 & 5,30 & 5,17 \\
\hline
\end{tabular}

lontar tersebut. Penelitian ini bertujuan untuk mempelajari pengaruh penambahan tepung tempe dari beragam konsentrasi terhadap peningkatan kadar protein dan citra rasa kecap nira lontar.

\section{Materi dan Metode}

Bahan dasar yang digunakan dalam penelitian ini yaitu nira lontar yang diambil dari penyadap lontar tradisional di Oesapa, Kupang, Nusa Tenggara Timur, dan tepung tempe yang dibuat dengan menghaluskan tempe yang diperoleh dari pedagang di pasar.

Metode penelitian yang digunakan dalam penelitian ini adalah metode eksperimen dengan perlakuan variasi konsentrasi tepung tempe yaitu $0 \%, 3 \%$, $5 \%, 7 \%$, dan $10 \%$, masing-masing perlakuan mempunyai 3 kali ulangan. Prosedur penelitian terbagi atas 3 tahap yaitu proses pembuatan kecap nira lontar, uji protein kecap nira lontar dan uji organoleptik.

Pembuatan kecap nira lontar dimulai dengan penyaringan $500 \mathrm{ml}$ nira lontar kemudian ditambahkan tepung tempe dengan variasi perlakuan sebagai berikut : A1 (tanpa penambahan tepung tempe), A2 (penambahan tepung tempe 15 gram), A3 (penambahan tepung tempe 25 gram, A4 (penambahan tepung tempe 35 gram), dan A5 (penambahan tepung tempe 50 gram). Beragam perlakuan antara campuran nira lontar dan tepung tempe dimasukan ke dalam wajan dan dimasak dengan menggunakan kompor api sedang. Kedalam setiap komposisi perlakuan yang sedang dimasak kemudian ditambahkan bumbu yang sudah dihaluskan, yang terdiri dari garam 1 sendok teh, sereh 1 batang, daun jeruk 2 lembar, lengkuas $1,25 \mathrm{~g}$, pekak 0,75 g, kemiri 7,5 g, wijen $5 \mathrm{~g}$, dan bawang merah.
Campuran dimasak selama 2 jam hingga mengental, kemudian didinginkan dan dikemas dalam botol.

Uji kandungan protein kecap nira lontar dilakukan dengan metode Kjeldahl sedangkan uji organoleptik dilakukan menggunakan uji Hedonik yang dilakukan pada 30 orang panelis dengan metode skoring meliputi rasa, warna dan aroma dengan skala numerik ( 5 = sangat suka, $4=$ suka, $3=$ biasa, $2=$ kurang suka dan 1 = tidak suka). Data uji hedonik yang diperoleh selanjutnya dianalisis dengan uji BNT dengan taraf kepercayaan 5\%.

\section{Hasil}

Kandungan Protein Pada Kecap Nira Lontar Dengan Variasi Konsentrasi Tepung Tempe

Kecap nira lontar merupakan sebuah produk pangan yang dihasilkan melalui hasil proses karamelisasi nira lontar dengan pemanasan. Dalam penelitian ini dilakukan pengayaan tepung tempe dalam berbagai konsentrasi pada kecap nira lontar.

Hasil analisis kandungan protein nira lontar dengan variasi konsentrasi tepung tempe menggunakan metode Kjeldahl dapat dilihat pada Tabel 1.

\section{Uji Organoleptik}

Uji Hedonik merupakan pengujian organoleptik yang didasarkan pada tingkat kesukaan panelis terhadap parameter penilaian yang didasarkan pada alat indra yang meliputi warna, tekstur, aroma dan rasa. Penelitian ini menggunakan panelis konsumen sebanyak 30 orang, dengan skala penilaian 1 - 6. Data hasil analisis Beda Nyata Terkecil (BNT) untuk mengetahui kesukaan konsumen terhadap kecap nira lontar pada parameter warna, kekentalan, aroma dan rasa kecap nira lontar ditampilkan pada Tabel 2. 


\section{Pembahasan}

Kandungan gizi nira lontar berupa karbohidrat dan protein membuat nira lontar dapat digunakan sebagai bahan dasar pembuatan kecap. Penambahan tepung tempe pada kecap nila lontar bertujuan untuk meningkatkan kandungan protein kecap nira lontar. Tepung tempe dibuat dari tempe sebagai bahan pangan yang dibuat dari fermentasi kedelai. Proses fermentasi yang terjadi akibat kerja kapang tempe berfungsi untuk mengubah senyawa makromolekul protein, lemak, dan karbohidrat) kompleks yang terdapat pada kedelai menjadi senyawa yang lebih sederhana seperti peptida, asam amino, asam lemak dan monosakarida. Senyawa sederhana ini lebih mudah dicerna di dalam tubuh dibandingkan yang terdapat dalam kedelai. Kedelai yang telah diproses menjadi tempe juga mengalami penambahan jumlah serat (Bastian et al., 2013).

Berdasarkan hasil analisis kandungan protein kecap nira lontar seperti yang tersaji di Tabel 1, kadar protein tertinggi terdapat pada perlakuan dengan variasi tepung tempe $10 \%$ (A5) yaitu sebesar 4,90\%. Penambahan tepung tempe dengan konsentrasi $10 \%$ menjadikan kecap nira lontar yang awalnya memiliki kandungan protein 2,58\% (perlakuan A1, tanpa penambahan tepung tempe) mengalami peningkatan kandungan protein sebesar 98\% dan melampaui nilai standar protein terlarut sebesar 2,5\% pada Standar Nasional Indonesia u (Anonim, 2013). Kandungan protein terendah terdapat pada perlakuan kecap nira lontar dengan penambahan $3 \%$ tepung tempe (A2) yaitu 3,17\%. Jika dibandingkan dengan kontrol (A1) maka perlakuan A2 mengalami kenaikan $82 \%$.

Keseluruhan hasil yang terangkum pada Tabel 1 menunjukan bahwa semakin besar konsentrasi tepung tempe yang ditambahkan ke dalam kecap nira lontar, maka semakin tinggi pula kandungan protein pada kecap nira lontar tersebut.

Berdasarkan hasil uji Beda Nyata Terkecil (BNT), terdapat perbedaan hasil kesukaan terhadap parameter warna, kekentalan, aroma, dan rasa yang dhasilkan oleh komposisi kecap nira lontar yang diujikan (Tabel 2). Penentuan kualitas bahan makanan pada umumnya sangat tergantung pada beberapa faktor, salah satunya adalah warna. Secara visual warna sangat menentukan kualitas bahan pangan (Winarno, 2002). Warna kecap nira lontar yang dihasilkan dari setiap perlakuan hampir sama jika dibandingkan antar perlakuan dan dengan warna kecap yang berasal dari kedelai. Warna dari air nira sebagai bahan dasar kecap nira lontar akan mengalami perubahan yang sama dengan kecap kedelai, namun tetap terdapat perbedaan berdasarkan penilaian panelis. Menurut Winarno (1983), dalam pengolahan pangan warna hasil akhir diperoleh dari kombinasi beberapa peristiwa perubahan warna karena reaksi kimia dan fisika akibat pemasakan. Warna penting baik bagi makanan yang diproses maupun yang tidak diproses dan memegang peranan penting dalam aspek penerimaan masyarakat (De Man, 2003).

Kekentalan merupakan parameter yang penting pada produk kecap, karena dapat digunakan sebagai kontrol terhadap proses pengolahan. Hasil uji BNT pada kecap nira lontar yang diperkaya dengan tepung tempe berbagai konsentrasi menunjukkan perbedaan hasil pada parameter kekentalan. Tingkat kekentalan kecap nira lontar dipengaruhi oleh penambahan tepung tempe serta durasi dan suhu pemasakan. Menurut Finallika et al. (2015), pemanasan dapat merubah sifat fisik dan kimiawi suatu zat. Semakin lama durasi pemasakan akan menghasilkan tekstur kecap nira lontar yang semakin kental. Naiknya suhu yang diakibatkan proses pemasakan bisa menghambat aktivitas enzim invertase mikroorganisme, sehingga sukrosa yang terdapat dalam nira lontar tidak mengalami banyak kerusakan. Pengaruh suhu dalam pemanasan juga dapat membunuh mikroorganisme patogen.

Aroma adalah sensasi dari senyawa volatil yang diterima oleh sel sensorik rongga hidung. Aroma makanan dapat digunakan sebagai indikator kelezatan bahan makanan dan berkaitan dengan alat panca indera (Winarno, 2002). Aroma makanan yang disebarkan oleh produk makanan melalui indera penciuman dapat membangkitkan 
selera makan (Wijaya, 2009). Berdasarkan hasil uji BNT pada aroma kecap nira lontar juga menunjukkan perbedaan pada setiap perlakuan. Oleh karena bahan dasar yang menjadi bumbu kecap nira lontar dalam penelitian ini adalah sama, perbedaan aroma pada setiap perlakuan kemungkinan besar disebabkan oleh perbedaan konsentrasi tepung tempe yang diberikan pada tiap perlakuan. Tepung tempe mempunyai aroma khas langu. Timbulnya aroma langu disebabkan oleh aktivitas dari kapang tempe seperti Rhizopus oligosporus sebagai spesies kapang utama dalam pembuatan tempe. Aktivitas kapang ini meliputi aktivitas protease dan lipase yang tinggi serta amilolitik yang rendah sehingga menghasilkan antioksidan yang mengakibatkan aroma langu yang khas pada tempe (Koswara, 1995). Menurut Istianah (2001), pada dasarnya nira memiliki aroma yang khas karena mengandung benzyl alkohol, suatu senyawa aromatik yang mudah menguap. Penggunaan nira mampu meningkatkan kemanisan dan karakteristik aroma kecap melalui proses pemasakan (Wiratma,1995),

Parameter terakhir yang diuji dalam uji hedonis adalah cita rasa kecap nira lontar. Uji BNT menunjukkan terdapatnya perbedaan persepsi panelis terhadap cita rasa kecap nira lontar tiap perlakuan. Rasa merupakan faktor yang sangat dominan dalam menentukan penerimaan atau penolakan terhadap seseorang terhadap bahan pangan. Menurut Negri et al. (2012), kemampuan mengenal rasa juga terkait kemampuan manusia untuk membedakan bahan pangan yang layak dikonsumsi atau tidak untuk kelangsungan hidupnya. Cita rasa yang baik atau enak mencakup rasa manis dan umami yang dihasilkan senyawa karbohidrat dan protein sebagai ciri pangan bernutrisi, sedangkan cita rasa yang tidak enak mencakup pahit dan asam bisa menjadi indikasi potensi senyawa beracun dalam suatu bahan pangan. Cita rasa asin bisa termasuk cita rasa yang enak atautidak enak tergantung konteks fisiologis tubuh (Negri et al., 2012). Hasil penelitian ini juga menunjukkan bahwa kecap nira lontar dengan pengayaan konsentrasi tepung tempe tertinggi $(10 \%)$ paling disukai panelis. Secara umum, rasa manis yang dimiliki kecap nira lontar berasal dari bahan dasar nira yang mengandung 75-90\% sukrosa (Naiola, 2008). Cita rasa manis dalam suatu bahan pangan ditentukan oleh kadar gula reduksi yang dikandung bahan pangan tersebut. Semakin manis rasa nira lontar sebagai bahan dasar kecap nira lontar menunjukkan semakin tingginya kadar gula reduksi. Menurut Rohmaningsih (2008), kadar gula reduksi nira bisa mengalami penurunan akibat perlakuan konsentrasi gula dan lama pemanasan. Cita rasa manis juga bisa didukung oleh penambahan bumbu yang digunakan dalam pembuatan kecap manis seperti lengkuas, pekak, kemiri, bawang putih dan kluwek (Annisa, 2013).

Secara keseluruhan, uji hedonis menunjukkan bahwa penambahan tepung tempe dengan konsentrasi tertinggi $(10 \%)$ pada kecap nira lontar menghasilkan warna, kekentalan, aroma dan cita rasa yang paling disukai oleh responden.

\section{Kesimpulan}

Penggunaan tepung tempe pada pembuatan kecap nira lontar sebagai bahan penyedap makanan tradisional masyarakat Nusa Tenggara Timur meningkatkan kandungan protein kecap nira lontar. Semakin tinggi konsentrasi tepung tempe yang ditambahkan dalam formulasi kecap nira lontar menyebabkan semakin tingginya kadar protein dalam kecap nira lontar. Uji organoleptik menunjukkan bahwa penambahan konsentrasi tertinggi tepung tempe pada kecap nira lontar menghasilkan tingginya kesukaan panelis akan produk kecap nira lontar tersebut.

\section{Daftar Pustaka}

Annisa,F., Wignyanto., \& Sakunda Anggarini. (2013). Pemanfaatan Dan Pengolahan Limbah Padat Industri Tahu Menjadi Kecap Bubuk (Kajian Konsentrasi Penambahan Bubur Nanas Dan Maltodekstrin). [Skripsi]. Universitas Brawijaya, Malang, Indonesia.

Anonim.(2013). Kecap Manis. Badan Standardisasi Nasional Indonesia. SNI 01-3543.1-2013. 
Astawan, M. (2004). Teknologi Pengolahan Pangan Nabati. Jakarta: Akamedika Presindo.

Bastian, F., Ishak, E., Tawali, A.B., \& Bilang, M. (2013). Daya Terima Dan Kandungan Zat Gizi Formula Tepung Tempe Dengan Penambahan Semi Refined Carrageenan (Src) Dan Bubuk Kakao. Jurnal Aplikasi Teknologi Pangan. 2(1) :5-8

De Man, J. M. (2003). Kimia makanan. Bandung: Penerbit ITB.

Finallika, E \& Widjanarko, S.B. (2015). Penentuan Nilai Maksimum Respon Rendemen Dan Gula Reduksi Brem Padat Tape Ubi Kayu (Manihotesculenta). Jurnal Pangan dan Agroindustri. 3 (2): 670-680

Istianah, A. (2001). “Pembuatan Kecap Kupang Merah (Musceelita senhausia) Kajian Lama Waktu Inkubasi dan Konsentrasi Enzim Papain terhadap Sifat Fisik Kimia dan Organoleptik". [Skripsi]. Universitas Brawijaya, Malang, Indonesia.

Koswara, S. (1995). Teknologi Pengolahan Kedelai Menjadikan Makanan Bermutu. Jakarta: Pustaka Sinar Harapan.

Mardiah. (1994). Sifat Fungsional dan Nilai Gizi Tepung Tempe Serta Pengembangan Produk Olahannya Sebagai Makanan Tambahan Bagi Anak. Institut Pertanian Bogor, Bogor.

Naiola, E. (2008). Mikrobia Amilolitik pada Nira dan Laru dari Pulau Timor, Nusa Tenggara Timur. Biodiversitas 9:165-168.

Negri, R., Di Feola, M., Di Domenico, S., Scala, M.G., Artesi, G., Valente, S., Smarrazzo, A., Turco,F., Morini, G., \& Greco, L. (2012). Taste Perception and Food Choices. JPGN, 54: 624-629

Rohmaningsih. (2008).Pengaruh Cara Pengeringan Terhadap Kadar Gula Reduksi Pada Sale Pisang. [Skripsi] FakultasSains d an TeknologiUniversitas Islam Negeri Sunan Kalijaga, Yogyakarta.

Sasongko. D. A. (2008). Sekilas Lontar. Kabe, 04(2) : 29-30.

Snyder, H.E \& Kwon, T.W. (1987).Soybean Utilization.Van Nostrand Reinhold Company, New York.
Wijaya, H. (2009). Sensasi Rasa Foodreview Indonesia: Bogor.

Winarno, F. G. (2002). Kimia Pangan dan Gizi. Jakarta, PT. Gramedia Pustaka Utama.

Winarno, F. G \& Fardiaz. (1983). Teknologi Pangan. Jakarta: Gramedia Pustaka Utama.

Wiratma, E. (1995). Analisis Flavor Kecap Manis. [Skripsi]. Institut Pertanian Bogor, Bogor, Indonesia. 